\title{
ENVIRONMENTAL EDUCATION IN RURAL AREAS - A REAL SUPPORT FOR SUSTAINABLE DEVELOPMENT
}

\section{EDUCAṬIA ECOLOGICĂ ÎN SPAȚIILE RURALE - UN SUPORT REAL PENTRU DEZVOLTAREA DURABILĂ}

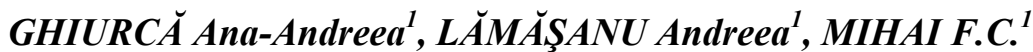 \\ e-mail: anaandreeaghiurca@yahoo.com
}

\begin{abstract}
Sustainable development represents the future for Romanian rural areas and a viable solution to solve the environmental problems. This concept can be put into practice through the interaction between economic, sociocultural, environmental and political-institutional dimension. In this interaction an important role has the ecological education of citizens from rural areas and their involvement in environmental policy decisions. So, a low level of ecological education in rural areas leads to a permanent degradation of environmental factors. In this research we showed some negative environmental practices related to the inhabitants of rural areas. Citizen's education in environmental spirit should promote the principles of prevention, conservation and recycling.
\end{abstract}

Key words: sustainable development, ecological education, rural space.

Rezumat. Dezvoltarea durabilă reprezintă viitorul spațiilor rurale româneşti şi o soluție viabilă pentru rezolvarea problemelor de mediu. Acest concept poate fi pus în practică prin interacțiunea dintre dimensiunea economică, socio-culturală, de mediu şi politico-instituțională. În această interacțiune un rol important $\hat{l}$ joacă educația ecologică a locuitorilor din spațiile rurale precum şi implicarea acestora în deciziile politicii de mediu. Astfel, un nivel scăzut al educației ecologice în spațiile rurale conduce la degradarea contiună a factorilor de mediu. In acest studiu am surprins câteva practici ale locuitorilor din mediul rural, care afectează calitatea mediului natural. Educația ecologică a cetățenilor ar trebui să promoveze principiile de prevenire, conservare și reciclare.

Cuvinte cheie: dezvoltare durabilă rurală, educație ecologică, spațiu rural.

\section{INTRODUCTION}

The study of rural areas from the sustainable development perspective requires a complex and detail analysis of the interaction between economic, socio-cultural, environmental and political-institutional dimensions. Sustainable rural development is a multidimensional and inter-temporal process, which is based on the concepts of equity, sustainability, competitiveness and governance (Sepúlveda, 2008).

Reshaping the Romanian rural area is a difficult task for contemporary society because it involves the establishment of a balance between rural

\footnotetext{
1 “Alexandru Ioan Cuza” University of Iasi, Romania
} 
conservation and upgrading rural lifestyle (Păun et al, 2006). European environment policies are difficult to apply in rural areas due to economic and social reasons.

\section{MATERIAL AND METHOD}

The present study aims to identify environmental problems faced by the rural population in Suceava and Neamț County, with direct examples of Gârcina and Râşca commune. For Râşca commune we made field observations in two seasons (April and September 2011), by highlighting the degradation of environmental factors in time.

For the county level research we used data from the past 10 years, made available by local Environmental Protection Agencies. In rural areas studied, we identified, following observations in various aspects of land degradation, high environmental factors degradation. Thus, we observed improper practices like: waste dumping (forest residues and animal waste), burning of agricultural debris and producing charcoal by rudimentary techniques. All these activities lead to degradation of air, water and soil, affecting the local natural resources.

\section{RESULTS AND DISCUSIONS}

The degree of the environmental factors degradation is correlated with the ecological education degree of the rural population. Often, education is not the only cause that contributes to environmental pollution; the economic situation and the disinterest of local authorities for environmental issues are in most cases responsible for the existing reality on the field. In this research we highlighted some negative environmental practices, carried out by population of rural areas.

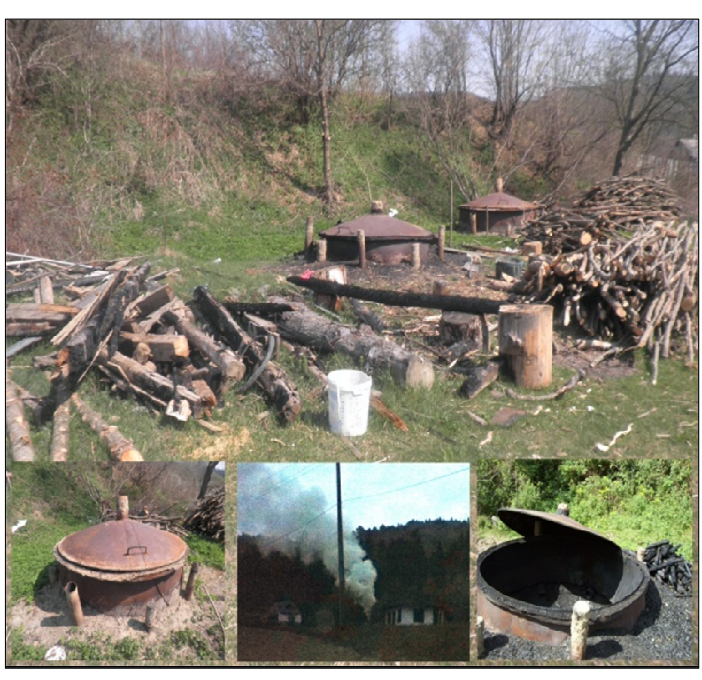

Fig. 1 - Air pollution by producing charcoal
A first example is represented by air pollution through charcoal production and agricultural waste burning. The charcoal production thought rudimentary techniques and equipment represents a source of income for some people, but the generated smoke leads to air local environmental pollution. In Râşca commune these illegal activities are practiced in unimproved spaces, close to living space, affecting the air quality (fig 1). 
In rural areas of Suceava County, the air quality is no longer monitored due to the introduction of automatic stations, in 2008 and 2010, in only four locations. So, the latest information about particulate matter (PM-10), in rural areas, which the Environmental Protection Agency from Suceava gave, was since 2007. It is observed that air pollution was much more intense in areas of hills and plateaus due to the higher density of the population in rural areas (fig. 2). As regards the Neamt County, air quality is not monitored at the rural level, automatic stations being located in urban areas (fig. 3).

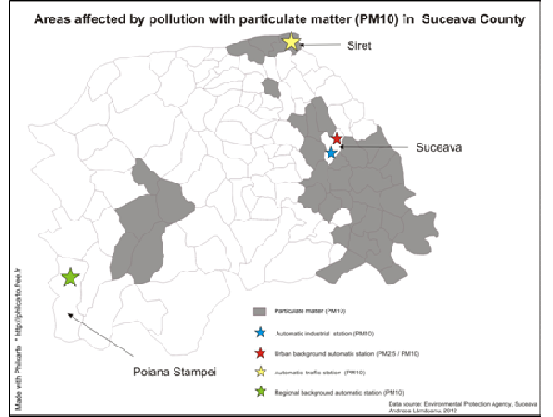

Fig. 2 - Areas affected by pollution with particulate matter (PM-10) and the location of automatic stations in Suceava County

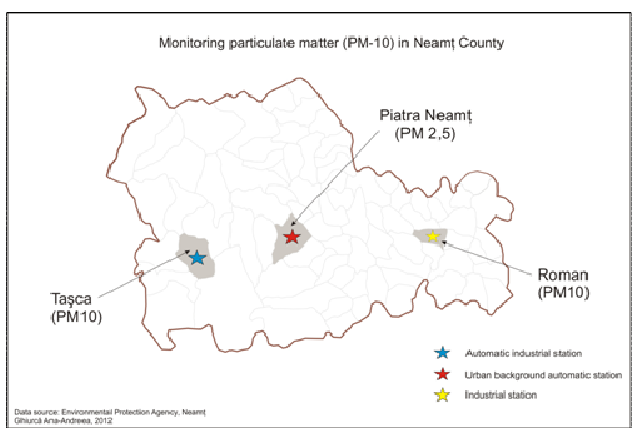

Fig. 3 - Monitoring particulate matter (PM 10) in Neamț County

The water pollution is caused by uncontrolled waste deposits located in river banks (Fig. 4). The categories of waste are varying from the biodegradable to the products result from primary processing of wood (sawdust, shavings) or construction.
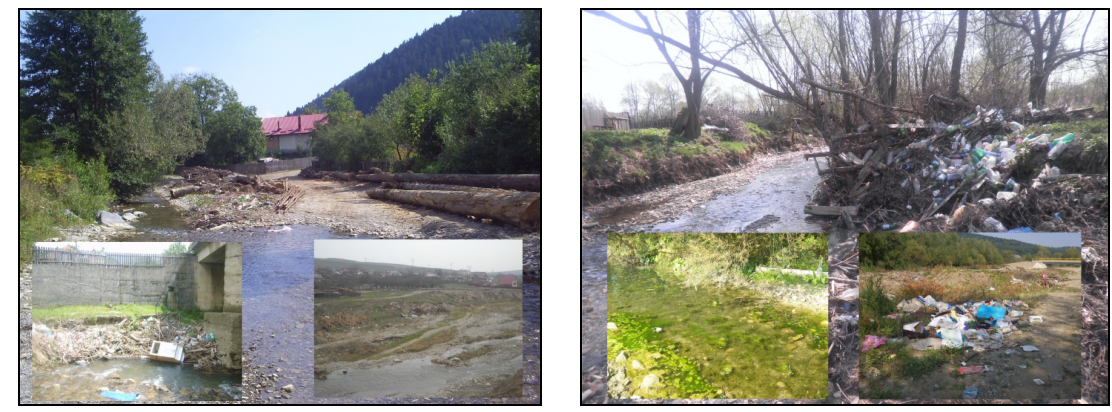

Fig. 4 - Uncontrolled waste in Cuejdiu and Râşca riverbeds

In the Suceava and Neamț County most rural mountain areas are affected by illegal deposits of sawdust situated in the immediate approach of rivers or even in their banks. In time, the sawdust degradation leads to changes the chemical composition of water, affecting aquatic wildlife by reducing the 
percentage of oxygen dissolved in water and accelerating the eutrophication process (Chiriac, 2011).

April
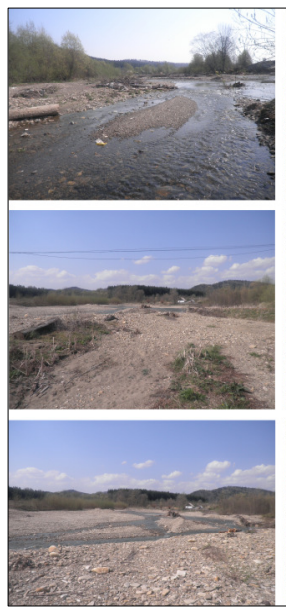

Fig. 5 - Field observations about waste stored in the river beds - Râşca commune
In Râşca commune, the field observations from April 2011 and September showed that the volume of generated and uncollected waste significantly grew in a short time (fig. 5). In order to avoid as far as possible environmental pollution, the European Union has ordered the construction of organic deposits and closing the old ones until 16 July 2009. Building new storages in Romania has not been completed by that date, creating an unpleasant situation, the sanitation services costs have increased due to the necessity of waste transportation to landfill nearby.

Most affected are rural areas, where some local authorities have abandoned the sanitation services for financial reasons (Lămăşanu and Mihai, 2011).

According to data provided by the Environmental Protection Agency, the percentage of rural population served by sanitation services, in Suceava County, grew at $2.85 \%$ in 2003 to $71.2 \%$ in 2009 , but has not reached the levels predicted by the local authorities that estimate for 2009 a rate of $90 \%$ (fig. 6). In Neamt County, the number of rural population served by sanitation services remained constant in the last 10 years, so that in 2008 , only $10 \%$ of population benefits of waste collection services (fig. 7).

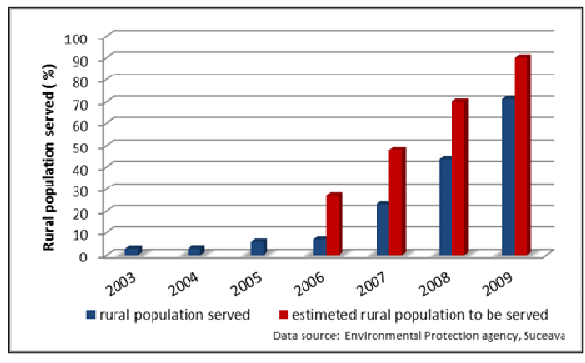

Fig. 6 - Actual and estimated rural population served by sanitation services in Suceava County

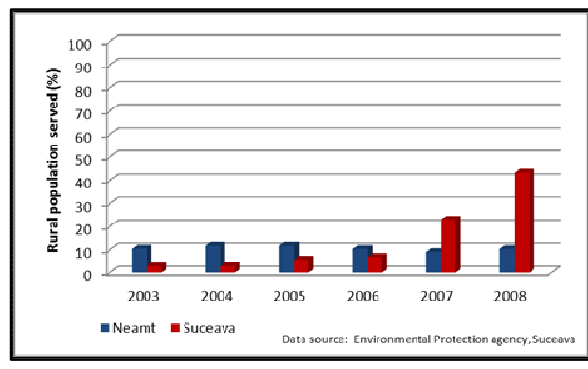

Fig. 7 - Actual rural population served by sanitation services in Suceava and Neamt County

The improper storage of animal waste and forestry residues from primary wood processing affects the soil quality (fig. 8). The degradation takes place through infiltration of large amounts of nitrates and through acidification. 

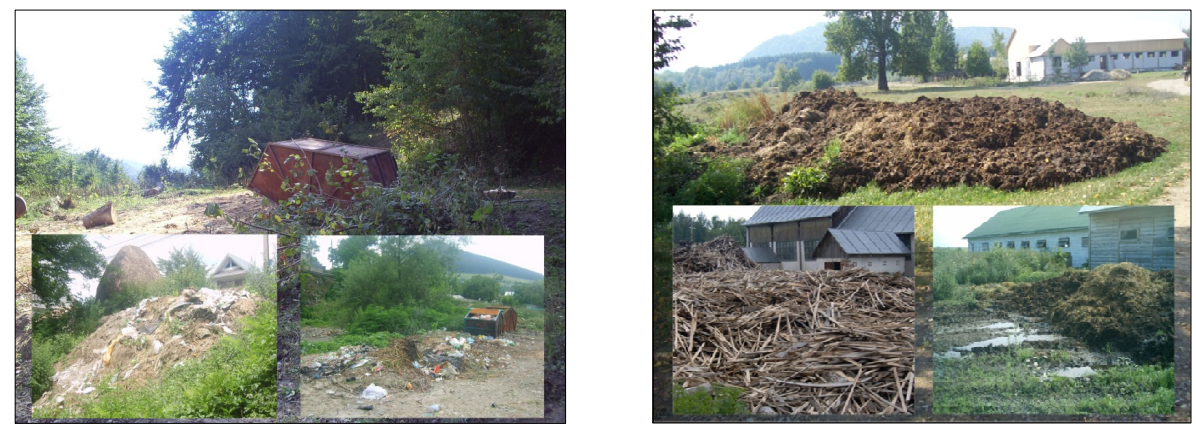

Fig. 8 - Uncontrolled waste directly storaged on the soil in Gârcina and Râşca Commune

Another environmental issue that affects the quality of the soil is represented by the incorrect agricultural practices. Thus, the soil degradation by acidification, compaction and erosion is a proof of the low degree of the environmental education among farmers. According to data collected by the Environmental Protection Agency, in 2007, in Suceava County many areas are affected by soil degradation through acidification, compaction and erosion (fig. 9). It is noted that in rural mountain areas, the soil degradation is mainly due to acidification, which may be the result of uncontrolled storage wood exploited.

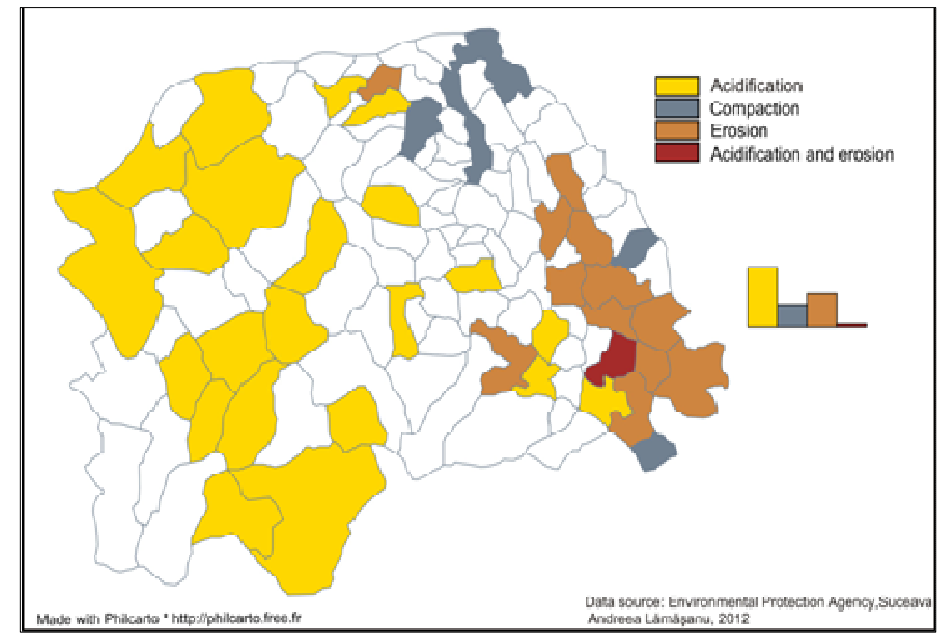

Fig. 9 - Soil degradation through acification, compaction and erosion in Suceava County

Public awareness on environmental protection can be done through greening campaign, introducing ecological courses in schools. Educating children is a major task for teachers, who are trainers of future generations, through educational projects to support sustainable development (Castillo et al, 2002). 


\section{CONCLUSIONS}

1. As it has been remarked in the rural areas, the lack of education is not only responsible for environmental issues, but also the economic situation and the interests of local authorities for the protection of the environment.

2. The quality of environmental factors in the areas analyzed is affected by pollution caused by inappropriate behavior of the locals, but also because of local authority's disinterest. As we have seen in the field observation from Râşca commune, the environmental pollution can be achieved in a short time (six month) but its effects will be felt for a long time.

3. The studied communes are one of many examples of rural areas which are facing problems related to pollution of air, water, soil, but in particular with the management of waste; improvements and their solution can be achieved only with the support of the local population and through financial support, resulting from the implementation of environmental projects.

Acknowledgements: This work was supported by the European Social Fund in Romania, under the responsibility of the Managing Authority for the Sectorial Operational Program for Human Resources Development 2007-2013 [grant POSDRU/107/1.5/S/78342].

\section{REFERENCES}

1. Castillo A., Garcia-Ruvalcaba S., Martinez R., Luis M., 2002 - Environmental education as facilitator of the use ecological information: a case study in Mexico. Environmental Education Research, 8 (4), p. 396-411.

2. Chiriac A., 2011 - Cercetări privind reducerea gradului de poluare în exploatarea şi prelucrarea lemnului, Universitatea Tehnică "Gheorghe Asachi" laşi, Facultatea de Inginerie Chimică şi Protecția Mediului, Teză de doctorat, rezumat, p. 36.

3. Lămaşanu A., Mihai F.C., 2011 -The illegal dumping of waste in forest areas. Evidence from rural territory. In: Integrated Management of Environmental Resources, International Conference, Suceava, Romania, November 4-6th 2011, Proceedings in print.

4. Păun I.O., Badea M.E., Băneş A., 2006 - Dezvoltarea rurală durabilă în România. Editura Academiei Române, Bucureşti, p. 31.

5. Sepúlveda S., 2008 - Géstion del desarrollo sostenible en territorios rurale: métodos para la planificación. Instituto Interamericano de Cooperación para la Agricultura, San José, Costa Rica, p. 12.

6. ${ }^{* * *}, 2007$ - Raport privind starea mediului în județul Suceava. Agenția de Protecția Mediului Suceava, p. 48-49, 81.

7. ***, 2010 - Raport privind starea mediului în județul Suceava. Agenția de Protecția Mediului Suceava, p. 70.

8. ***, 2010 - Raport privind starea mediului în județul Neamț. Agenția de Protecția Mediului Neamt, p. 80.

9. ***, 2008 - Plan Județean de Gestionare a Deşeurilor - Județul Suceava, Consiliul Județean Suceava, p. 95. 